\title{
New distribution records of Chaltenobatrachus grandisonae (Anura: Batrachylidae) in Patagonia, Chile
}

\author{
Helen Díaz-Páez ${ }^{1,2 *}$, Nicza Alveal ${ }^{1,3}$, Ingrid Cisternas-Medina $^{1,3}$ and Juan Carlos Ortiz ${ }^{2,3}$ \\ 1 Universidad de Concepción, Departamento de Ciencias Básicas, Escuela de Educación, Campus Los Ángeles, Juan Antonio Coloma 0201, \\ Zip Code 4451032, Los Ángeles, Chile \\ 2 Centro de Investigación en Ecosistemas de la Patagonia (CIEP), Francisco de Bilbao 323, Zip Code 5951511, Coihaique, Chile \\ 3 Universidad de Concepción, Departamento de Zoología, Facultad de Ciencias Naturales y Oceanográficas, Barrio Universitario, Casilla \\ 160-C, Zip Code 4089100, Concepción, Chile \\ * Corresponding author. E-mail: hediaz@udec.cl
}

\begin{abstract}
Chaltenobatrachus grandisonae was first collected in Puerto Edén, Wellington Island, Magallanes Region, Chile, where the species has never been found again. Subsequently Basso et al. (2011) found it in two new localities in Lago del Desierto and Lago Nansen, Santa Cruz province, southern Patagonia, Argentina. Recently Cisternas et al. (2013) reported its presence in Laguna Caiquenes, Aysén Region, Chile. Our results provide distribution data between the northern and southern locations in Chile, and we confirm the presence of the species in Chilean Patagonia.
\end{abstract}

Key words: Chaltenobatrachus, distribution, Patagonia, Chile

Chaltenobatrachus grandisonae (Lynch, 1975) is a poorly known species, and for many years the taxonomic status of this frog was confused. It was first collected during December 1958 at Puerto Eden, Wellington Island, Chile, by the Royal Society Expedition to South Chile and deposited at the British Museum (Natural History) and described as a member of the genus Telmatobius (Lynch 1975). It was later reassigned to the genus Atelognathus based on morphological characters (Lynch 1978). However, Basso et al. (2011) placed it into the new genus Chaltenobatrachus Basso, Úbeda, Bunge \& Martinazzo, 2011. The genus is monotypic and the sister taxon of the genus Atelognathus Lynch, 1978, and is known only from southern Patagonia.

Chaltenobatrachus grandisonae has been found in the localities of Lago del Desierto $\left(49^{\circ} \mathrm{O} 4^{\prime} 41^{\prime \prime} \mathrm{S}, 072^{\circ} 54^{\prime} 17^{\prime \prime}\right.$ $\mathrm{W})$ and Lago Nansen ( $48^{\circ} \mathrm{O} 5^{\prime} \mathrm{Oo}$ " S, $072^{\circ} 25^{\prime} \mathrm{OO} \mathrm{O}^{\prime \prime} \mathrm{W}$ ) in Argentine southern Patagonia, and in Chile at Puerto Edén, Isla Wellington ( $49^{\circ} 10^{\prime} \mathrm{oo}^{\prime \prime} \mathrm{S}, 074^{\circ} 28^{\prime} \mathrm{Oo} \mathrm{o}^{\prime \prime} \mathrm{W}$ ) (Lynch 1975; Basso et al. 2011) and Laguna Caiquenes
( $47^{\circ} 49^{\prime} 58^{\prime \prime} \mathrm{S}, 073^{\circ} 18^{\prime} 16^{\prime \prime} \mathrm{W}$ ) (Cisternas et al. 2013) (Figure 1). The species is associated with Nothofagus forest, in both temporary and permanent pools. Basso et al. (2011) examined different larval states, indicating that the larvae have a prolonged development and overwinter in water. Cisternas et al. (2013) observed that the eggs are deposited in temporary ponds in areas of forest regeneration.

Field observations were performed during springsummer season of 2007-2010 in Chilean Patagonia. We surveyed both aquatic and terrestrial habitat adjacent to streams. Animals were identified as $C$. grandisonae by morphological characters such as uniform bright green dorsal coloration, with brown to reddish warts, thin dorsal skin, orange iris, tympanum absent and fingers with evident inter-digital webbing (Basso et al. 2011).

The specimens were euthanized with $1 \%$ benzocaine and fixed in 10\% formalin for subsequent preservation in $70 \%$ ethanol. We recorded sex and anatomic diagnostic characters immediately after euthanasia (Table 1). We found specimens of $C$. grandisonae at three localities (Figure 1). The first of these was in Laguna Caiquenes (Figure 2a and 2b), recently reported by Cisternas et al. (2013). The other two are new localities for this species: Lago Balboa ( $47^{\circ} 53^{\prime} \mathrm{Oo} \mathrm{o}^{\prime} \mathrm{S}, 073^{\circ} \mathrm{O} 6^{\prime} \mathrm{oo}$ " W) (Figure $2 \mathrm{C}$ and 2d), and near Villa O'Higgins ( $48^{\circ} 22^{\prime} \mathrm{Oo}^{\prime \prime} \mathrm{S}, 072^{\circ} 29^{\prime} \mathrm{oo}$ " W) (Figure 2e and 2f). Specimens were deposited in the collection of Museo de Zoología de la Universidad de Concepción (MZUC 35391; 36565; 32533; 33710; 33722; 33762; 32980). Collections were made under permit from the Servicio Agrícola y Ganadero (SAG), resolutions 6494 / 2006 and 6491 / 2007.

The habitat of $C$. grandisonae is wet forest of Nothofagus, dominated by lengas (N. pumilio) and coigües ( $N$. betuloides), with bogs of Poaceae and Cyperaceae. The specimens were found on the edges of 
Table 1. Morphological measurements of Chaltenobatrachus grandisonae ( $\mathrm{mm}$.). The specimens from new localities are grouped by sex and are compared with the data from holotype [BM (1962.629)] according to Lynch (1975) and Basso et al. (2011).

\begin{tabular}{|c|c|c|c|c|}
\hline $\begin{array}{l}\text { Body measure } \\
(\mathrm{mm})\end{array}$ & Holotype (Lynch 1975) & $\begin{array}{l}\text { C. grandisonae } \\
\text { Basso et al. } 2011\end{array}$ & $\begin{array}{l}\text { C. grandisonae } \\
n=9 \text { males }\end{array}$ & $\begin{array}{l}\text { C. grandisonae } \\
n=7 \text { females }\end{array}$ \\
\hline Snout-Vent length & 32.9 & $37.13 \pm 2.39$ & $35.62 \pm 3.15$ & $32.32 \pm 6.10$ \\
\hline Head width & 10.8 & $11.34 \pm 0.62$ & $11.03 \pm 0.66$ & $10.25 \pm 1.86$ \\
\hline Head height & 10.6 & $11.27 \pm 0.62$ & $11.78 \pm 0.91$ & $10.71 \pm 1.98$ \\
\hline Femur length & 14.0 & $16.09 \pm 1.44$ & $16.18 \pm 2.33$ & $15.38 \pm 3.88$ \\
\hline Foot length & & $23.69 \pm 1.23$ & $20.34 \pm 3.05$ & $20.09 \pm 3.84$ \\
\hline Upper eyelid width & 3.2 & $3.00 \pm 0.49$ & $2.65 \pm 0.61$ & $2.28 \pm 0.64$ \\
\hline Interorbital distance & 2.1 & $2.99 \pm 0.32$ & $3.09 \pm 0.43$ & $2.87 \pm 0.27$ \\
\hline Eye diameter & 3.7 & $3.51 \pm 0.16$ & $3.53 \pm 0.58$ & $3.20 \pm 0.63$ \\
\hline Nostril-eye distance & 2.5 & $2.53 \pm 0.21$ & $2.73 \pm 0.36$ & $2.60 \pm 0.57$ \\
\hline
\end{tabular}

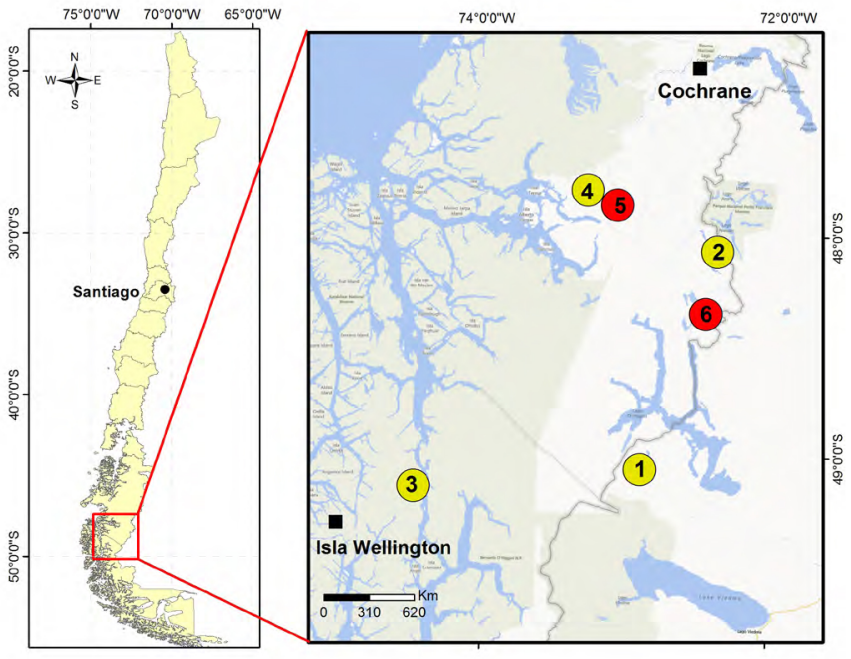

Figure 1. Distribution of Chaltenobatrachus grandisonae. Known localities: (1) Laguna del Desierto; 2 Lago Nansen; 3 Puerto Edén, Isla Wellington; 4 Laguna Caiquenes. New localities: 5 Lago Balboa; 6 Villa O'Higgins.

ponds, hidden under the vegetation or rocks. In these localities, $C$. grandisonae cohabits with other anurans: Alsodes sp., Batrachyla antartandica Barrio, 1967; Eupsophus calcaratus (Günther, 1881) and Nannophryne variegata Günther, 1870. In Chile this species was listed as "Rare" (Reglamento de la Ley de Caza, Chile 1998), but our data confirm that Chaltenobatrachus grandisonae occurs in remote, inaccessible Patagonian territories, including natural protected areas. The information given here shows new records of the presence $C$. grandisonae in Chile and therefore it is possible that it is not threatened. On the other hand, the lack of knowledge of its natural history and population biology does not allow us to accurately assess its conservation status, so we recommend maintaining it as Data Deficient, "in view of continuing uncertainties as to its taxonomic status, extent of occurrence and ecological requirements" (IUCN 2014).

\section{ACKNOWLEDGEMENTS}

We thank Jonathan Guzman, Pabla Hernandez and Marcela Vidal for their enthusiastic assistance in the

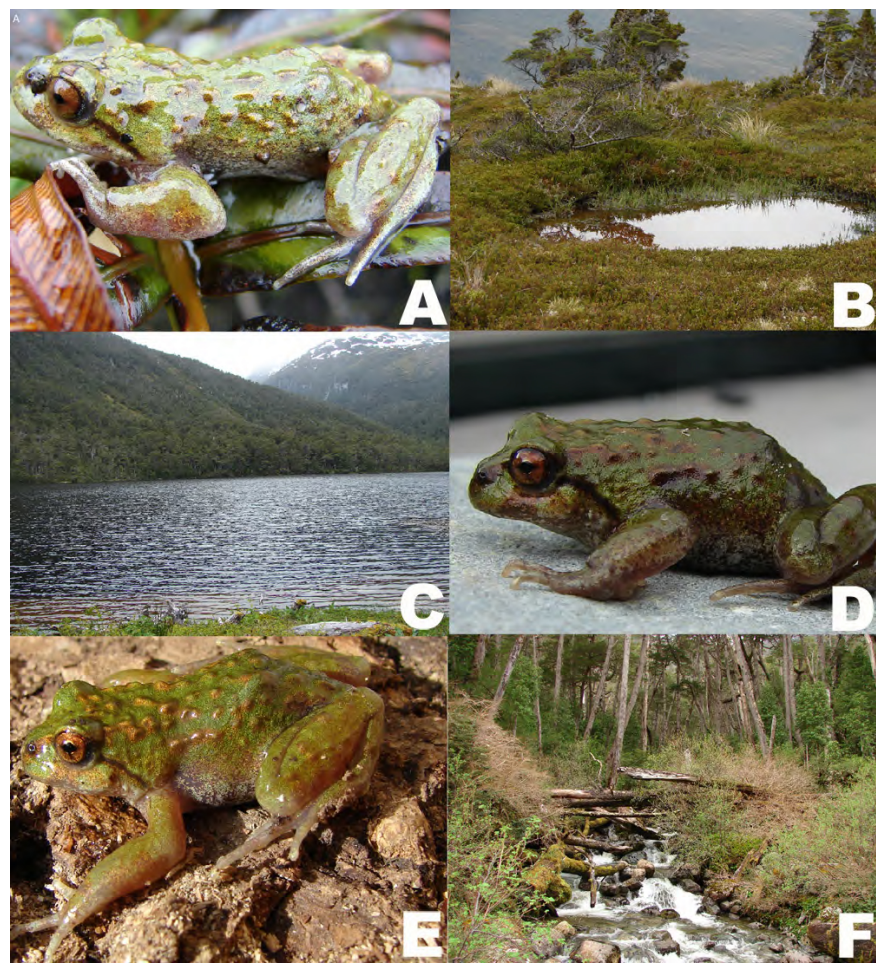

Figure 2. Specimens and habitat of $C$. grandisonae from the Aysén region in Chile. (A) C. grandisonae from Lago Balboa, (B) Temporary pond in open area, (C) Laguna Caiquenes, (D) C. grandisonae from Laguna Caiquenes, (E) C. grandisonae from Villa O'Higgins, (F) Stream where larvae and adults in breeding season are found.

field. Dr. Lafayette Eaton helped translating earlier versions of this manuscript. This research was funded by the project 210.412.045-1sp de HDP.

\section{LITERATURE CITED}

Basso, N.G., C.A. Úbeda, M.M. Bunge and L.B. Martinazzo. 2011. A new genus of neobatrachian frog from southern Patagonian forests, Argentina and Chile. Zootaxa 3002: 31-44. http://www. mapress.com/zootaxa/2011/f/zto3oo2po44.pdf

Cisternas, J., C. Correa, N. Velasquez and M. Penna 2013. Reproductive features of Chaltenobatrachus grandisonae (Anura: Batravhylidae) within a protected área in Patagonia, Chile. Revista Chilena de Historia Natural 86: 365-368. doi: 10.4067/ So716-078X2013000300013

IUCN. 2014. IUCN Red List of threatened species. Version 2010.4. 
Electronic database accessed at http://www.iucnredlist.org, 2 June 2014.

Lynch, J.D. 1975. A new chilean frog of the extra-Andean assemblage of Telmatobius (Amphibia: Leptodactylidae). Southern California Academy of Sciences Bulletin 74(3): 160-161. http://biostor.org/ reference/101998

Lynch, J.D. 1978. A re-assessment of the Telmatobiine leptodactylid frogs of Patagonia. Occasional Papers of the Museum of Natural History the University of Kansas 72(1): 1-57. http:// biodiversitylibrary.org/page/4138180
Authors' contribution statement: $\mathrm{HD}-\mathrm{P}$ and JCO collected the data; HD-P, NA wrote the text and made figures; NA, IC-M made measurements of specimens, IC-M prepared the map.

Received: 17 July 2014

Accepted: 28 April 2015

Academic editor: Marcelo N. de C. Kokubum 